\title{
СОВРЕМЕННОЕ СОСТОЯНИЕ И ОТДЕЛЬНЫЕ НАПРАВЛЕНИЯ РАЗВИТИЯ ВЗАИМНОЙ ТОРГОВЛИ СТРАН - ЧЛЕНОВ ЕАЭС В УСЛОВИЯХ ПАНДЕМИИ COVID-19
}

\author{
Ю.И. Енин, Н.А. Подобед, Л.С. Пацай*
}

\begin{abstract}
Раскрыты проблемы, связанные с современным состоянием взаимной торговли в Евразийском экономическом союзе. В качестве индикатора уровня интеграции исследованы основные показатели взаимной и внешней торговли стран ЕАЭС. Выявлены тенденции развития торговых отношений, предложены инструменты их активизации, а также возможные пути увеличения объема взаимной торговли в ЕАЭС на основе взаимодействия с КНР и ЕС.
\end{abstract}

Ключевые слова: взаимная торговля, интеграция, инновации, инфраструктура, ЕАЭС.

JEL-классификация: F14, F15.

DOI: $10.46782 / 1818-4510-2021-3-29-39$

Материал поступил 30.03.2021 2.

Международная экономическая интеграция с различной скоростью развивается во всех регионах мирового хозяйства. При этом современный ее этап имеет для экономик стран Евразии свои особенности.

Во-первых, данный этап международной интеграции связан с активными процессами мировой глобализации, стремительным развитием информационных технологий и быстро формирующейся «цифровой экономикой». Конференция ООН по торговле и развитию (ЮНКТАД) ввела в научный оборот новый термин «цифровая экономика», которую трактуют как «применение цифровых интернет-технологий в процессе производства товаров и услуг и торговли ими» (Головенчик, 2018. С. 28).

Во-вторых, на постсоветском пространстве в интеграционные союзы объединяются европейские и азиатские независимые государства. На территории континента появилось и функционирует несколько международных интеграционных образований, имеющих разнонаправленные и раз- носкоростные векторы сотрудничества, среди них ЕАЭС, ЕС, ШОС, СНГ, Союзное государство.

В-третьих, в странах - членах ЕАЭС происходит модернизация транспортно-логистической инфраструктуры с целью обеспечения качественной экономической интеграции транспортных и логистических систем Союза в мировую транспортную систему, что позволит активизировать ее внутреннюю и внешнюю торговлю (Енин, Подобед, 2020. С. 4).

В-четвертых, стратегии государств членов ЕАЭС формируются с учетом транзитного потенциала и возможностей Союза во внешней торговле с КНР и ЕС, что отражается на особенностях их торговли на современном этапе. Например, Национальная стратегия устойчивого социальноэкономического развития Республики Беларусь на период до 2030 г. предполагает расширение внешнеэкономических связей за счет международных транспортных коридоров, проходящих через ее территорию.

* Енин Юрий Иванович (yryenin@gmail.com), доктор экономических наук, профессор, Белорусский государственный экономический университет (г. Минск, Беларусь). https://orcid.org/0000-0001-5866-1109;

Подобед Наталья Александровна (trans80@inbox.ru), кандидат экономических наук, доцент, Белорусский государственный экономический университет (г. Минск, Беларусь). https://orcid.org/0000-0002-0302-3924;

Пацай Лидия Сергеевна (lidiamax@rambler.ru), кандидат экономических наук, Белорусский государственный экономический университет (г. Минск, Беларусь). https://orcid.org/0000-0002-0848-8675 


\section{Особенности Евразийской экономической интеграции на современном этапе}

Евразийская экономическая интеграция представляет собой эволюционный процесс сближения национальных экономик на основе заинтересованности сторон. Идеи евразийства, отражающие политические и торгово-экономические отношения славянских народов с кочевыми империями степей Евразии, имеют глубокие исторические и гносеологические корни. Основные элементы теории евразийства и неоевразийства раскрыты в трудах известных историков, экономистов, политиков (Г.В. Вернадский, Л.П. Карсавин, Л.Н. Гумилев и др.) (Подобед, Енин, 2019. С. 351).

Теоретико-методологический подход к анализу евразийской интеграции чрезвычайно актуален и важен для понимания современного состояния международной торговли и перспектив интернационализации хозяйственной деятельности стран в регионах данного континента.

Выделим некоторые аспекты экономической интеграции в Евро-Азиатском регионе.

1. В ней представлены разные уровни и формы - «Союз» (ЕС и Союзное государство), «Экономическое сообщество» (ЕАЭС), «Содружество» $($ СНГ).

2. В международные интеграционные объединения входят не только развитые страны (как, например, в ЕС), но и развивающиеся, и государства с переходной экономикой, что несколько усложняет процесс сопряжения экономических систем различного уровня.

3. Формируется один из ведущих центров мировой экономики, что связано с двумя глобальными проектами: создание механизмов сопряжения экономики ЕАЭС и реализация инициативы КНР в рамках Нового Экономического пояса шелкового пути.

4. На территории Евразии сконцентрированы основные трудовые и природные ресурсы, накоплен огромный потенциал для создания глобального интеграционного союза на базе существующих международных объединений, находящихся на разных этапах своего развития.

Сегодня основной целью Евразийского экономического союза стало преодоле- ние центробежных процессов на территории СНГ. Республика Беларусь, Российская Федерация, Республика Казахстан, Кыргызская Республика, Республика Армения находятся на пути центростремительного развития (экономической интеграции), формируя ядро ЕАЭС.

Юридической основой функционирования современного ЕАЭС является Договор о создании Евразийского экономического союза, подписанный в Астане 29 мая 2014 г., который закрепил основные положения международных соглашений в рамках Таможенного союза и Единого экономического пространства.

Важнейшую роль в экономике ЕАЭС играет промышленность, формирующая около 27\% суммарного объема ВВП входящих в него стран. В 2020-2021 гг. пандемия COVID-19 оказала негативное влияние на все сферы экономики стран - членов международного интеграционного объединения, затронув в том числе промышленность. В результате этого промышленное производство по ЕАЭС в 2020 г. снизилось на 2,8\%. Единственным государством-членом, где отмечено наращивание объемов промышленного производства, стала Армения (0,5\% прироста). Неплохие результаты показала ее обрабатывающая промышленность. Следует отметить положительный результат Казахстана (3,2\% прироста), благодаря которому не произошло более серьезного снижения показателей обрабатывающей промышленности в целом по всему международному объединению.

По данным Евразийской экономической комиссии, единый рынок услуг в ЕАЭС охватывает порядка $50 \%$ объема оказываемых услуг (без учета финансовых). Процесс либерализации в отношении еще 10\% услуг (без учета финансовых) будет происходить в течение переходного периода. Особые режимы регулирования применяются для транспортных услуг и услуг электросвязи.

В ЕАЭС продолжается планомерная работа по расширению единого рынка путем включения секторов, которые пока еще не гармонизированы в части правил международной торговли. Это рынки нефти и нефтепродуктов, алкоголя, табака, автомобилей, газа 
и др. Более активное использование инструментов наднационального регулирования различных рынков в ЕАЭС, как свидетельствуют принятые в последнее время документы, прогнозируется не ранее 2025 г.

Постепенно возрастает вовлеченность ЕАЭС в мировую торговлю: в 2019 г. доля данного объединения в мировом товарообороте составила $2,2 \%$, что на 0,23 п. п. выше показателя 2015 г. Также за указанный период зафиксирован рост экспорта в третьи страны не только минеральных продуктов, но и несырьевых товаров на 19\%, включая сельскохозяйственную группу товаров и высокотехнологичную продукцию.

В целях достижения «четырех свобод» в соответствии с Договором о ЕАЭС государства-члены координируют или согласуют политику в различных отраслях экономики.

В своей деятельности ЕАЭС приходится учитывать и использовать опыт наиболее продвинутого интеграционного объединения - Евросоюза. ЕС имеет значительный опыт в построении торгово-экономических отношений с другими международными объединениями. Так, ЕС и МЕРКОСУР сформировали межрегиональную зону свободной торговли (Енин, Змачинская, 2009). Необходимо отметить, что ЕАЭС решает весьма схожие задачи, однако в данном случае речь идет об интеграции государств с отличающимися экономическими условиями (например, по темпам экономического и промышленного роста, уровню безработицы и некоторым другим макропоказателям).

Несмотря на мировые кризисные явления и современную пандемию, в течение шести лет существования Евразийского экономического союза взаимная торговля ее странчленов имела достаточно стабильную динамику. По сравнению с 2015 г. взаимный экспорт в 2019 г. возрос на 34\%, причем товарная структура достаточно диверсифицирована и включает в себя товары как конечного потребления, так и промежуточные.

Практика торговли показывает, что в условиях кризисных явлений усиливается активность в области применения мер нетарифного регулирования в рамках международного регионального объединения. Это обусловлено необходимостью защиты национальных интересов стран-участниц, ус- транения негативных тенденций в области внешнеторгового оборота и др. В целом в начале XXI в. применение нетарифных мер в мировом хозяйстве значительно активизировалось, они выступают в качестве барьеров и регуляторов внешней торговли.

В рамках ЕАЭС основным наднациональным органом является Евразийская экономическая комиссия (ЕЭК), которая регулирует вопросы таможенно-тарифного и нетарифного регулирования, формирует общие санитарные, ветеринарные и фитосанитарные правила и нормы; устанавливает торговые режимы и формирует ввозные таможенные пошлины; ведет статистику внешней и взаимной торговли; распределяет промышленные и сельскохозяйственные субсидии; осуществляет защиту результатов интеллектуальной деятельности (Геврасёва, 2016. С. 45).

Нетарифные методы регулирования, которые активно применяют государства ЕАЭС, можно условно подразделить на 3 основные группы: прямые ограничения, специальные нетарифные методы, административные методы.

Прямыми ограничениями являются лицензирование и квотирование. Лицензирование подразумевает выдачу государством разрешительных документов в форме лицензий на экспорт и импорт отдельных видов товаров. Лицензии могут быть разовыми, генеральными и исключительными. Без наличия государственной лицензии экспорт или импорт продукции субъекта хозяйствования практически невозможен.

Квотирование - это достаточно популярный инструмент нетарифного регулирования в ЕАЭС, который позволяет вводить количественные и стоимостные ограничения как для ввозимых, так и для вывозимых товаров. Квотирование бывает индивидуальным, глобальным, сезонным и тарифным. Как правило, на практике квотирование применяется в качестве временной меры для регулирования торговли на определенный период.

К спещиальным нетарифным методам относят разного рода пошлины (специальные, антидемпинговые, компенсационные), а также импортные квоты. Антидемпинговые пошлины применяются государством 
в случае угрозы одной из отраслей из-за чрезмерно низкой цены импортного товара. Использование в ЕАЭС компенсационных пошлин позволяет ликвидировать конкурентное преимущество иностранных компаний-экспортеров, получающих поддержку от своего государства. Специальные пошлины применяются при риске ущерба экономикам стран - членов ЕАЭС и вводятся только в исключительных случаях после комплексного расследования.

Административные методы нетарифного регулирования включают налоги и сборы на импортируемые товары, сертификацию и др. К мерам нетарифного регулирования также относят некоторые методы поддержки экспорта и валютный контроль.

Количественно оценить степень воздействия мер нетарифного регулирования на внутреннюю торговлю ЕАЭС возможно на основе оценки частоты и степени применения нетарифных мер в отношении конкретных позиций номенклатуры таможенного тарифа (в мировой практике, Frequency Index). Этот показатель говорит об общем уровне использования нетарифных мер в конкретной стране на основе сопоставления числа национальных товарных позиций, в отношении которых применяются нетарифные меры, с общим числом товарных позиций национального таможенного тарифа (Геврасёва, 2016. С. 17). Данный метод характеризует степень использования нетарифных мер в странах - членах ЕАЭС или в целом по международному объединению. Однако он не показывает реальный уровень протекционистской защиты национального рынка с помощью нетарифных мер.

\section{Современное состояние взаимной торговли стран - членов ЕАЭС}

При анализе состояния и направлений развития взаимной торговли стран - членов EAЭС в условиях пандемии COVID-19 важное значение имеет оценка их социально-экономического положения в 2020 г. и перспективы сотрудничества на среднесрочный срок. В 2020 г. в целом по ЕАЭС наблюдалось снижение основных социально-экономических показателей, за исключением объема производства продукции сельского хозяйства и выполненных строительных работ (табл. 1).

Валовой внутренний продукт, рассчитанный производственным методом, в январе-сентябре 2020 г. составил 1255 117,9 млн долл. США. Индекс физического объема ВВП по ЕАЭС за приведенный период 2020 г. был равен 96,7\% к уровню соответствующего периода 2019 г. (в 2019 г. по сравнению с 2018 г. - 101,6\%, а в 2018 г. по сравнению с 2017 г. - 102,7\%).

В общем объеме ВВП стран - членов ЕАЭС основная доля принадлежит Российской Федерации (около 86,4\%), на втором месте находится Казахстан (8,9\%), третье место занимает Республика Беларусь (3,5\%) (рис. 1).

Валовой внутренний продукт в целом по Евразийскому экономическому союзу

Таблица 1 и странам-членам, 2020 г.

\begin{tabular}{|c|c|c|c|c|}
\hline \multirow[b]{2}{*}{ Страна } & \multicolumn{3}{|c|}{ Январь - сентябрь 2020 г. } & \multirow{2}{*}{$\begin{array}{c}\text { Январь-сентябрь } 2019 \text { г. } \\
\text { \% к январю-сентябрю } \\
2018 \text { г. } \\
\text { (в постоянных ценах) }\end{array}$} \\
\hline & $\begin{array}{c}\text { млрд ед. национальной } \\
\text { валюты } \\
\text { (в текущих ценах) }^{*}\end{array}$ & $\begin{array}{c}\text { млн долл. } \\
\text { США }\end{array}$ & $\begin{array}{c}\text { \% к январю-сентябрю } \\
2019 \text { г. } \\
\text { (в постоянных ценах) }\end{array}$ & \\
\hline Армения & 4283,9 & 8844,5 & 93,4 & 107,6 \\
\hline Беларусь & 106,4 & 43963,9 & 98,8 & 101,2 \\
\hline Казахстан & 45803,3 & 112117,3 & 97,2 & 104,3 \\
\hline Кыргызстан & 415,1 & 5493,5 & 93,7 & 105,9 \\
\hline Россия & 76547,2 & 1084698,7 & 96,6 & 101,0 \\
\hline ЕАЭС & - & 1255117,9 & 96,7 & 101,3 \\
\hline
\end{tabular}

* Армения - арм. драмы; Беларусь - бел. руб.; Казахстан - тенге; Кыргызстан - сомы; РФ - рос. руб.

Источник. URL: http://www.eurasiancommission.org/ru/act/integr_i_makroec/dep_stat/tradestat/analytics/ Documents/2020/Analytics_I_202012.pdf 


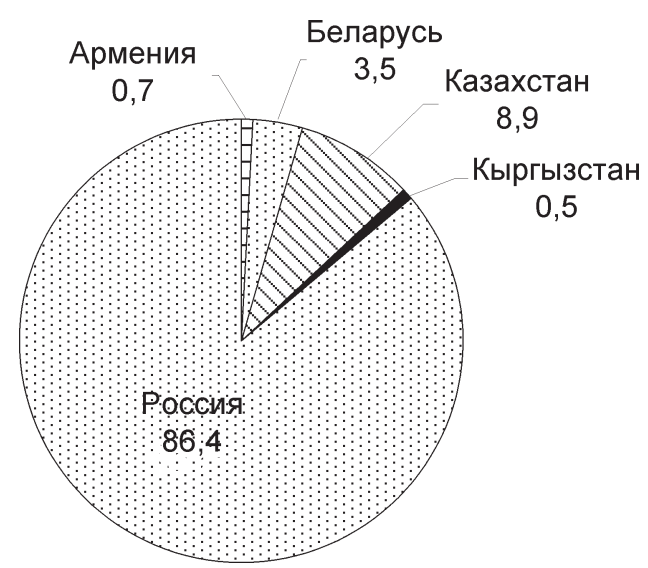

Рис. 1. Распределение объема валового внутреннего продукта по государствам - членам ЕАЭС в январе-сентябре 2020 г.

Источник: Авторская разработка на основе: URL:http://www.eurasiancommission.org/ru/act/ integr_i_makroec/dep_stat/econstat/Documents/ Brief_Indicators/Brief_indicators2020_12.pdf.

Процессы, вызванные пандемией инфекции COVID-19, также негативно повлияли на экономику ЕАЭС. Так, индекс промышленного производства в 2020 г. по сравнению с 2019 г. составил 97,3\%, оборота розничной торговли - 95,9\%, грузооборота $-93,9 \%$ (табл. 2). При этом наибольшее снижение наблюдалось в пассажирообороте - индекс 55,7\%. Положительной тенденцией в 2020 г. по сравнению с 2019 г. являлось увеличение индекса объема производства сельскохозяйственной продукции (102,3\%) и индекса объема выполненных строительных работ (100,7\%) (табл. 2).
Отметим, что товарная структура экспортно-импортных операций стран - участниц Евразийского экономического союза близка к товарной структуре взаимной торговли стран СНГ и в основном ориентирована на традиционные для них товарные группы и потоки. Развитие взаимной торговли товарами в 2020 г. происходило в условиях экономического спада из-за пандемии COVID-19. Поэтому ее объем за 2020 г. составил 54,9 млрд долл. США, или $89 \%$ к уровню соответствующего периода 2019 г. Следовательно, можно констатировать, что развитие взаимной торговли стран ЕАЭС в 2020 г. замедлилось (табл. 3).

В товарной структуре взаимной торговли стран - членов ЕАЭС традиционно наибольший удельный вес занимают минеральные продукты (21,6\% объема взаимной торговли). При этом существенны поставки на союзный рынок машин, оборудования и транспортных средств (20\%), а также продовольственных товаров и сельскохозяйственного сырья $(17,9 \%)$, металлов и изделий из них (13,1\%). На динамику взаимной торговли в 2020 г. по сравнению с 2019 г. повлияло уменьшение поставок инвестиционных (на 14,6\%), потребительских (на 1,3\%) и промежуточных товаров (на $14,8 \%$ ), из которых определяющим стало снижение торговли энергетическими товарами (на 29,7\%).

Наибольшую долю в поставках на рынок ЕАЭС традиционно занимает Российская Федерация (62,1\% от общего объема

Таблица 2

Основные экономические показатели ЕАЭС, 2020 г., \%

\begin{tabular}{|l|r|r|r|r|r|r|}
\hline \multicolumn{1}{|c|}{ Показатель } & ЕАЭС & Армения & Беларусь & Казахстан & Кыргызстан & Россия \\
\hline ВВП & 96,7 & 93,4 & 98,8 & 97,2 & 93,7 & 96,6 \\
\hline Промышленное производство & 97,3 & 99,1 & 99,3 & 99,3 & 93,4 & 97,1 \\
\hline Производство продукции с/х & 102,3 & 101,5 & 104,9 & 105,6 & 101,1 & 101,5 \\
\hline Инвестиции в основной капитал & 95,8 & 84,3 & 97,9 & 95,1 & 85,7 & 95,9 \\
\hline Объем выполненных строительных работ & 100,7 & 98,1 & 95,4 & 111,2 & 72,4 & 100,1 \\
\hline Грузооборот & 93,9 & 100,7 & 93,2 & 93,4 & 78,4 & 94,3 \\
\hline Пассажирооборот & 55,7 & 35,9 & 81,4 & 35,2 & 57,5 & 71,4 \\
\hline Оборот розничной торговли & 95,9 & 82,3 & 101,8 & 95,9 & 82,3 & 95,9 \\
\hline Индекс потребительских цен & 103,9 & 101,2 & 105,5 & 106,8 & 106,3 & 103,4 \\
\hline $\begin{array}{l}\text { Индекс цен производителей } \\
\text { промышленной продукции }\end{array}$ & 97,2 & 102,4 & 105,6 & 92,0 & 120,8 & 97,7 \\
\hline
\end{tabular}

Источник. URL: http://www.eurasiancommission.org/ru/act/integr_i_makroec/dep_stat/econstat/Documents/ Brief_Indicators/Brief_indicators2020_12.pdf 
Динамика взаимной торговли ЕАЭС, 2016-2020 гг., млн долл. США

\begin{tabular}{|c|c|c|c|c|c|c|c|c|c|}
\hline \multirow[b]{2}{*}{ Страна } & \multirow[b]{2}{*}{2016 г. } & \multirow[b]{2}{*}{2017 г. } & \multirow[b]{2}{*}{2018 г. } & \multirow[b]{2}{*}{2019 г. } & \multirow[b]{2}{*}{2020 г. } & \multicolumn{4}{|c|}{ Темп роста, \% } \\
\hline & & & & & & $\begin{array}{c}2017 \text { г. } \\
\text { к } \\
\text { уровню } \\
2016 \text { г. }\end{array}$ & $\begin{array}{c}2018 \text { г. } \\
\text { к } \\
\text { уровню } \\
2017 \text { г. }\end{array}$ & $\begin{array}{c}2019 \text { г. } \\
\text { к } \\
\text { уровню } \\
2018 \text { г. }\end{array}$ & $\begin{array}{c}2020 \text { г. } \\
\text { к } \\
\text { уровню } \\
2019 \text { г. }\end{array}$ \\
\hline Армения & 393,9 & 557,2 & 689,0 & 769,2 & 705,3 & 141 & 124 & 111,7 & 91,7 \\
\hline Беларусь & 13,4 & 7,0 & 11,7 & 17,9 & 21,3 & 52 & 167 & 150,0 & 118,7 \\
\hline Казахстан & 5,0 & 4,9 & 9,8 & 5,4 & 6,4 & 98 & 200 & 55,3 & 119,3 \\
\hline Кыргызстан & 1,0 & 1,8 & 1,0 & 3,2 & 1,6 & 180 & 56 & в $3,2 \mathrm{p}$. & 51,3 \\
\hline Россия & 374,5 & 543,5 & 666,5 & 742,7 & 676,0 & 145 & 123 & 111,6 & 91,0 \\
\hline Беларусь & 11384,8 & 13651,1 & 13891,8 & 14569,7 & 14008,7 & 120 & 102 & 104,6 & 96,1 \\
\hline Армения & 22,0 & 34,5 & 37,4 & 52,7 & 57,5 & 157 & 108 & 140,2 & 109,2 \\
\hline Казахстан & 363,9 & 592,3 & 783,9 & 765,5 & 747,4 & 163 & 132 & 97,7 & 97,6 \\
\hline Кыргызстан & 48,7 & 123,5 & 120,3 & 60,7 & 66,6 & 254 & 97 & 50,4 & 109,7 \\
\hline Россия & 10950,2 & 12900,8 & 12950,2 & 13690,8 & 13137,2 & 118 & 100 & 105,4 & 96,0 \\
\hline Казахстан & 3930,2 & 5262,6 & 5892,0 & 6406,2 & 5539,0 & 134 & 112 & 105,9 & 86,5 \\
\hline Армения & 0,6 & 5,6 & 7,5 & 4,4 & 7,3 & 933 & 134 & 89,7 & 166,0 \\
\hline Беларусь & 47,2 & 101,2 & 87,5 & 106,8 & 69,6 & 214 & 86 & 101,6 & 65,1 \\
\hline Кыргызстан & 437,2 & 516,7 & 634,9 & 624,1 & 562,6 & 118 & 123 & 95,0 & 90,1 \\
\hline Россия & 3445,2 & 4639,1 & 5162,1 & 5670,9 & 4899,5 & 135 & 111 & 107,4 & 86,4 \\
\hline Кыргызстан & 445,5 & 541,5 & 568,4 & 641,7 & 546,3 & 122 & 105 & 100,2 & 85,1 \\
\hline Армения & - & 0,1 & 0,1 & 0,2 & 0,2 & - & 100 & 185,6 & 95,8 \\
\hline Беларусь & 3,3 & 7,1 & 7,0 & 13,1 & 10,6 & 215 & 99 & 109,0 & 81,1 \\
\hline Казахстан & 264,6 & 268,6 & 247,2 & 347,1 & 293,9 & 102 & 92 & 128,4 & 84,7 \\
\hline Россия & 177,6 & 265,7 & 314,1 & 281,3 & 241,6 & 150 & 118 & 78,5 & 85,9 \\
\hline Россия & 26804,3 & 34685,5 & 38679,9 & 39247,2 & 34061,8 & 129 & 112 & 100,8 & 86,8 \\
\hline Армения & 962,5 & 1247,0 & 1341,4 & 1690,9 & 1657,7 & 130 & 108 & 125,1 & 98,0 \\
\hline Беларусь & 15248,8 & 19573,8 & 22779,8 & 21709,7 & 16916,3 & 128 & 116 & 94,7 & 77,9 \\
\hline Казахстан & 9560,4 & 12465,4 & 12923,3 & 14286,9 & 14031,0 & 130 & 104 & 109,6 & 98,2 \\
\hline Кыргызстан & 1032,6 & 1399,3 & 1635,4 & 1559,7 & 1456,8 & 136 & 117 & 95,2 & 93,4 \\
\hline $\begin{array}{l}\text { Итого по } \\
\text { ЕАЭС } \\
\end{array}$ & 42958,7 & 54697,9 & 59721,1 & 61634,0 & 54861,1 & 127 & 109 & 102,3 & 89,0 \\
\hline
\end{tabular}

Источник. URL:http://www.eurasiancommission.org/ru/act/integr_i_makroec/dep_stat/econstat/Documents/ Brief_Indicators/Brief_indicators2020_12.pdf

взаимного экспорта в 2020 г.). Значительный вклад внесли Республика Беларусь $(25,5 \%)$ и Республика Казахстан $(10,1 \%)$. При этом доли Республики Армении и Кыргызской Республики относительно невелики (1,3 и 1\% соответственно).

Большая часть закупок в союзном товарообороте приходится на Республику Беларусь (35,9\% от общего объема взаимного импорта) и Российскую Федерацию (33,2\%). Республика Казахстан приобретает на союзном рынке 24,7\% от общего объема предложенных товаров, Кыргызская Республика $3,4 \%$, Республика Армения - 2,8\%.

Наибольшую ориентированность на рынок ЕАЭС демонстрирует Беларусь. Доля взаимной торговли с членами Союза во внешней торговле страны по итогам 2020 г. составила $49,5 \%$, в том числе $44,2 \%$ в экспорте и $56,2 \%$ в импорте товаров. Высокие показатели взаимодействия с рынком ЕАЭС зарегистрированы по Кыргызской Республике (42,5, 32,3 и $42,1 \%$ соответственно) и Республике Армения (34,0, 29 и 30,8\% соответственно). На рынок ЕАЭС приходится более пятой части внешней торговли Казахстана $(23,2 \%)$. При этом в страны-партнеры направляется $11 \%$ казахстанского экспорта. Доля закупок Казахстана на союзном рынке занимает 38,5\% от общего объема импорта страны.

Таким образом, результаты анализа взаимной торговли стран - членов ЕАЭС 
свидетельствуют о том, что назрела необходимость в более тесной экономической интеграции и кооперации, в том числе и для всех участников цепочек создания стоимости, каналов дистрибуции, потребителей, а отдельные отрасли экономики странпартнеров могли бы активнее интегрироваться на основе современных информационных цифровых платформ.

10 апреля 2020 г. в Минске Евразийский Межправительственной совет на уровне премьер-министров государств - членов ЕАЭС принял Распоряжение о срочных антикризисных и стабилизационных мерах, направленных на обеспечение экономической стабильности в период развития пандемии COVID-19, жизненно важных потребностей населения, на поддержание взаимной торговли, свободного передвижения товаров и создание условий для последующего экономического роста. В соответствии с Распоряжением был запущен «зеленый коридор» для импорта критически важных товаров, введены единые временные ограничения на экспорт критически важных товаров в третьи страны, увеличены объемы экспортных кредитов и предоставлены гарантии по их страхованию. Также будут реализованы меры гибкого применения механизма регулирования в финансовом секторе, в том числе смягчены административные нагрузки и условия кредитования бизнеса.

На наш взгляд, важнейшим интеграционным проектом ЕАЭС, способным переломить негативные экономические тенденции 2020 г., является реализация Карты индустриализации международного объединения. В настоящий время - это основной документ, определяющий импортозависимые технологические направления и импортозамещающий потенциал производителей стран-членов данного международного объединения. В Карте индустриализации содержатся планируемые значимые инвестиционные проекты на территории ЕАЭС, а также прописаны проекты более чем по 20 отраслям промышленности, инфраструктурного строительства, энергетики. Например, в Армении планируется реализовать проект $3 \mathrm{AO}$ «Каракертский завод каменного литья» по организации каменного литья из местного базальта для нужд горнодобывающей промышленности и транс- порта; в Беларуси - проекты по строительству авиаремонтного завода на территории Национального аэропорта «Минск», созданию комплекса замедленного коксования нефтяных остатков в ОАО «Нафтан»; в Киргизии - проект ОсОО «Белес.КG.» по крупноузловой сборке маршрутных автобусов городского назначения стандарта «евро-5»; в России - проект АО «Таурас-Феникс» по строительству завода, выпускающего фасовочно-упаковочное оборудование для пищевой промышленности, и некоторые другие проекты.

Следует отметить, что для активизации взаимной торговли в ЕАЭС проводится целенаправленная и поэтапная работа по ликвидации барьеров и ограничений. Задача полного устранения барьеров и максимального сокращения изъятий, ограничений для свободного передвижения товаров, услуг, капитала и рабочей силы на внутреннем рынке ЕАЭС является одной из приоритетных в работе Евразийской экономической комиссии, что нашло свое отражение в Стратегических направлениях развития евразийской экономической интеграции до 2025 г. Терминология препятствий и алгоритм устранения барьеров утверждены Решением Коллегии Евразийской экономической комиссии от 14.11.2017 г. № 152 «Методология разделения препятствий на внутреннем рынке Евразийского экономического союза на барьеры, изъятия и ограничения». В реестре препятствий фиксируются выявленные барьеры, а также те ограничения, которые планируются к устранению (табл. 4).

Согласно данным ЕАЭС за 2019 г., устранено 15 препятствий, из которых 11 барьеров, 1 ограничение, 3 изъятия. При этом в последнее время появилась следующая тенденция: новые ограничения в ЕАЭС появляются быстрее, чем устраняются старые. Так, если на январь 2018 г. в реестре насчитывалось 65 препятствий, в январе 2019 г. - 71, то в январе 2020 г. - 58 препятствий. Среди них 11 барьеров - это прямые нарушения норм ЕАЭС, 13 изъятий характеризуются отступлением от общих правил, 34 ограничения обусловлены отсутствием общей нормативной базы по данному направлению. Отметим, что лидером по количеству преград является Казахстан, который установил 46 
Динамика изменения количества препятствий на внутреннем рынке ЕАЭС, 2017-2020 гг.

\begin{tabular}{|l|c|c|c|c|c|c|}
\hline \multicolumn{1}{|c|}{ Препятствия } & 2017 г. & 2018 г. & Устранено & 2019 г. & Устранено & 2020 г. \\
\hline Барьеры & 9 & 11 & -10 & 16 & -11 & 11 \\
\hline Ограничения & 34 & 37 & -3 & 38 & -1 & 34 \\
\hline Изъятия & 17 & 17 & 0 & 17 & -3 & 13 \\
\hline Всего (реестр) & 60 & 65 & -13 & 71 & -15 & 58 \\
\hline
\end{tabular}

Источник. URL: https://www.economy.gov.by/ru/likv_izjatij-ru/

препятствий, на второй позиции - Беларусь (45 препятствий), Россия определила 43 ограничения, а Кыргызстан и Армения - по 42. В ЕАЭС препятствия зафиксированы в 15 сферах. При этом больше всего проблемных вопросов возникает в сфере технического регулирования (17 препятствий), транспортной сфере (6 препятствий) и в сфере энергетической политики (13 препятствий).

В настоящий момент Евразийская интеграция проходит сложный период, связанный с комплексом негативных факторов. Это падение цен на сырьевые товары, рост индекса потребительских цен, напряженность в международных политических и торговоэкономических отношениях, ухудшение общих прогнозов для мировой экономической системы из-за пандемии COVID.

Для преодоления негативных тенденций в рамках ЕАЭС принят комплексный документ «Стратегические направления развития евразийской экономической интеграции до 2025 года». В его рамках можно выделить следующие направления развития взаимной и внешней торговли:

полное устранение барьеров и максимальное сокращение ограничений для свободного передвижения товаров, работ, услуг, капитала и рабочей силы на внутреннем рынке Союза;

совершенствование таможенного регулирования, полная унификация таможенного законодательства стран - членов ЕАЭС;

формирование цифрового пространства и экосистем ЕАЭС;

расширение экономического сотрудничества в области образования, здравоохранения, туризма и спорта;

ускорение технологического развития промышленных комплексов;

реализация политики импортозамещения; наращивание экспорта промышленной продукции;

развитие единой транспортно-логистической инфраструктуры;

активизация торговых отношений с КНР и ЕС.

На страны ЕС приходится около 45\% торгового оборота ЕАЭС (доля экспорта стран - членов Союза в ЕС достигла 49\%, а доля импорта - 38\%), тогда как в 2014 г. эта доля достигала $52 \%$. Объемы поставок европейских товаров в последние годы имеют тренд на снижение.

Сегодня главным торговым партнером государств - членов ЕАЭС в Азии является Китай, занимающий 1-е место во внешнеторговом обороте Российской Федерации (доля Китая составляет 18,1\%), Кыргызской Республики (42,9\%), Республики Армения (15,8\%), Республики Казахстан $(19,2 \%)$ и 2 -е место во внешнеторговом обороте Республики Беларусь (12,6\%). При этом текущие темпы изменения основных социально-экономических показателей стран - членов ЕАЭС отстают от темпов развития передовых стран Азии. Одновременно увеличивается число торговых барьеров, с которыми товары и услуги ЕАЭС сталкиваются на трансграничных рынках. Все это является фактором сдерживания реального экономического роста в странах -членах ЕАЭС.

По итогам 2019 г. товарооборот между ЕАЭС и Китаем вырос на 5,7\%, увеличившись до 133,4 млрд долл. США (со 126,2 млрд долл. США в 2018 г.). Постепенно увеличивался как экспорт стран ЕАЭС в Китай, так и импорт из Китая. В 2019 г. рост экспорта стран ЕАЭС составил 5,4\% (с 62,9 млрд долл. США в 2018 г. до 66,3 млрд долл. США в 2019 г.). В свою очередь, импорт вырос на 6,1\% (с 63,3 млрд долл. США в 2018 г. до 67,2 млрд долл. 
США в 2019 г.). Одной из актуальных проблем 2020-2021 гг. для всего мира стала ликвидация негативных последствий пандемии COVID-19 для международной торговли.

\section{Основные направления развития торгово-экономических отночений в ЕАЭС}

1. Усиление экономической интеграции стран - членов Союза, в том числе международной научно-производственной кооперации для всех участников цепочки создания стоимости, каналов дистрибуции, потребителей. Отдельные отрасли национальных экономик могли бы интегрироваться на основе информационных цифровых платформ.

2. Активное участие в интересах ЕАЭС в китайской инициативе «Один пояс один путь». Предполагается использование финансовых инструментов нового поколения на базе технологии блокчейн, а также формирование системы децентрализованных финансов (DeFi). Например, с 1 января 2021 г. в РФ вступил в силу Федеральный закон «О цифровых финансовых активах, цифровой валюте», а Центральный банк КНР ввел национальную криптовалюту (DCEP) в четырех городах страны Шэньчжэне, Сюнъане, Чэнду и Сучжоу.

3. Создание евразийских сетей промышленной кооперации, субконтрактации и трансфера технологий для обеспечения взаимодействия на основе современных цифровых технологий. Важно развивать научно-техническое и инновационное сотрудничество, реализовывать проекты по импортозамещению в рамках стран - членов EАЭС.

4. Модернизация элементов транспортно-логистической инфраструктуры ЕАЭС, что позволит получить синергетический эффект за счет комплексного развития системы транспортных коммуникаций, индустриальных парков и элементов цифровой логистики (Подобед, Енин, 2019. С. 319320). Перспективное направление - создание сети транспортно-логистических центров, а также единой мультимодальной компании, осуществляющей экономическую интеграцию с национальными операторами ЕАЭС (Дюмулен, 2016). Следует актив- но использовать инструменты государственно-частного партнерства для модернизации элементов транспортно-логистической инфраструктуры и снятия торгово-экономических барьеров ${ }^{1}$.

Геополитические интересы стран ЕАЭС тесно связаны с развитием международного транспортного коридора «Запад - Восток» как важнейшего направления экономического роста. Участие государств-членов в цифровой модернизации элементов транспортно-логистической инфраструктуры увеличит транзит через территорию Союза и позволит повысить эффективность интеграционных процессов. Реализация крупных инфраструктурных проектов в рамках «Экономического пояса шелкового пути» предполагает строительство транспортно-логистических центров, индустриальных парков, сухих портов и т. д. В будущем данные элементы послужат основой для создания единой евразийской транспортно-логистической платформы, являющейся системным интегратором финансовых, инвестиционных и транспортных потоков из Европы и Азии.

Важным является создание дополнительных условий и экономических стимулов для формирования реального диалога на уровне ЕС - ЕАЭС и ЕАЭС - КНР с акцентом на предметную дискуссию о перспективах эффективного торгово-экономического сотрудничества. Необходимо углубление диалога с внешними партнерами ЕАЭС и ускорение подготовки нормативных документов по заключению соглашений о свободной торговле (ЗСТ). В целях минимизации последствий текущих тенденций мирового экономического кризиса, усиленного пандемией COVID-19, требуются комплексные меры стимулирования взаимной торговли в ЕАЭС, реализуемые на основе геоэкономических программ в рамках сопряжения ЕАЭС и китайской инициативы «Экономического пояса шелкового пути» (Кохно, Енин, 2020).

${ }^{1}$ Енин Ю.И., Подобед Н.А., Пилютик А.А. 2020. Маркетинговое регулирование транспортно-логистической инфраструктуры ЕАЭС: курс лекций. Минск: Право и экономика. 
По мере стабилизации мировой торговли и роста совокупного рынка ЕАЭС возникнут новые возможности и точки экономического роста как для зарубежных партнеров Союза в целом, так и для национальных компаний стран-членов в частности. Для этого целесообразно продолжать процесс модернизации транспортно-логистической инфраструктуры. Перспективным направлением для ЕАЭС является внедрение современных полностью роботизированных транспортно-логистических центров (Енин, Подобед, 2020. С. 6). В рамках управленческих решений на наднациональном уровне Союза целесообразно создание единой мультимодальной транспортно-логистической компании, осуществляющей экономическую интеграцию транзитных маршрутов за счет альянсов с национальными операторами ЕАЭС².

В рамках формирующейся единой инфраструктуры ЕАЭС - КНР важное место отводится обеспечению роста неценовой конкурентоспособности предприятий и организаций транспортно-логистического кластера; увеличению несырьевого и высокотехнологического экспорта товаров и услуг; стимулированию увеличения количества малых и средних предприятий в придорожно-сервисном кластере; модернизации железнодорожных и автомобильных дорог, формирующих международные транспортные коридоры (Подобед, 2020. C. 336).

\section{СПИСОК ЛИТЕРАТУРЫ (REFERENCES)}

Геврасёва А.П. 2016. Нетарифные методы регулирования и их влияние на развитие взаимной торговли в условиях Евразийского экономического союза. Труды БГТУ. № 7. С. 44-48. [Gevrasyova A.P. 2016. Non-tariff methods of regulation and their influence on development of mutual trade in the conditions of Eurasian Economic Union. Trudy BGTU. No 7. (In Russ.)]

2 Енин Ю.И., Пилютик А.А., Подобед Н.А. 2017. Инновационный менеджмент и маркетинг инноваций: курс лекций. Минск: Право и экономика.
Головенчик Г.Г. 2018. Цифровая экономика как новый этап глобализации. Цифровая трансформащия. № 1. C. 26-36. [Golovenchik G.G. 2018. Digital economy as a new stage of globalization. Tsifrovaya transformatsiya. No 1. PP. 26-36. (In Russ.)]

Дюмулен И.И. 2016. Нетарифные меры в современной международной торговле: некоторые вопросы теории, практика и правила ВТО, интересы России. Российский внешнеэкономический вестник. № 2. C. 3-20. [Dyumulen I.I. 2016. Non-tariff measures in modern international trade: Some questions of the theory; practice and rules of the WTO; Russia's interests. Rossiyskiy oneshneekonomicheskiy vestnik. № 2. PP. 3-20. (In Russ.)]

Енин Ю.И., Змачинская Ю.С. 2009. Формирование межрегиональной зоны свободной торговли ЕC-МЕРКОСУР. Минск: Право и экономика. [Enin Yu.I., Zmachinskaya Yu.S. 2009. Formation of an interregional free trade area EU-MERCOSUR. Minsk: Pravo i ekonomika. (In Russ.)]

Енин Ю.И., Подобед Н.А. 2020. Цифровая трансформация транспортно-логистической инфраструктуры ЕАЭС: факторы, уровни и особенности. Веснік Магілёўскага дзяржаўнага ўніверсітэта імя А.А. Куляиова. № 2. С. 4-11. [Yenin Yu.I., Podobed N.A. 2020. Digital transformation of the EAEU transport and logistic infrastructure: Factors, levels and features. Vesnik Magiley̆skaga dzyarzhaynaga universiteta imya A.A. Kulyashova. No 2. PP. 4-11. (In Russ.)]

Кохно П., Енин Ю. 2020. О закономерностях развития мировой экономики. Общество и экономика. Вып. 10. C. 5-36. [Kokhno P., Enin Yu. 2020. On the development patterns of the world economy. Obshchestvo i ekonomika. Iss. 10. PP. 5-36. (In Russ.)]

Подобед Н.А., Енин Ю.И. 2019. Формирование единой транспортно-логистической инфраструктуры в контексте евразийской интеграции. Научные труды Белорусского государственного экономического университета. С. 351-359. [Podobed N., Enin Yu. 2019. Formation of a unified transport and logistics infrastructure in the context of Eurasian integration. Nauchnye trudy Belorusskogo gosudarstvennogo ekonomicheskogo universiteta. PP. 351-359. (In Russ.)]

Подобед Н.А. 2020. Концептуальные основы развития транспортно-логистической инфраструктуры ЕАЭС. Социальная модернизаиия: российская спеиифика и некоторые уроки. Тамбов. C. 319-340. [Podobed N.A. 2020. Conceptual foundations for the development of the transport and logistics infrastructure of the EAEU. Sotsial'naya modernizatsiya: rossiyskaya spetsifika i nekotorye uroki. Tambov. PP. 319-340. (In Russ.)] 
In citation: Belorusskiy Ekonomicheskiy zhurnal. 2021. No 3. PP. 29-39.

Belarusian Economic Journal. 2021. No 3. PP. 29-39.

\title{
THE CURRENT STATE AND SEPARATE AREAS OF MUTUAL TRADE DEVELOPMENT IN THE EAEU MEMBER COUNTRIES UNDER THE COVID-19 PANDEMIC
}

\author{
Yurii Yenin ${ }^{1}$, Natalya Padabed $^{1}$, Lidziya Patsai $^{1}$ \\ Author affiliation: ${ }^{1}$ Belarusian State Economic University (Minsk, Belarus). \\ Corresponding author: Yurii Yenin (yryenin@gmail.com).
}

ABSTRACT. The article is devoted to a wide range of problems related to the current state of mutual trade in the Eurasian Economic Union. As the main indicator of the level of integration, the quantitative indicators of mutual and foreign trade of the EAEU countries were studied. The main trends in the development of trade relations are identified, tools for their activation are proposed. Based on the results of the scientific study, possible ways to increase the volume of mutual trade in the EAEU were proposed on the basis of interaction with China and the EU.

KEYWORDS: international trade, integration, innovation, infrastructure, EAEU.

JEL-code: F14, F15.

DOI: $10.46782 / 1818-4510-2021-3-29-39$

Received 30.03.2021 